\title{
Isolamento e caracterização biológica da amostra JAP99 do vírus da doença de Newcastle isolada de patos domésticos (Neta sp) no Rio de Janeiro
}

\author{
Isolation and biological characterization of JAP99 Newcastle disease virus isolated \\ from domestic ducks (Neta sp) in Rio de Janeiro State \\ Jorge Granja de Oliveira Júnior ${ }^{1}$ Paula Amorin Schiavo² ${ }^{2}$ uciano Doretto Júnior $^{3}$ \\ Maria Ângela Orsi ${ }^{4}$ Carlos Mazur ${ }^{5}$ Cláudio de Moraes Andrade ${ }^{6}$
}

\begin{abstract}
- NOTA -
RESUMO

O vírus da doença de Newcastle (VDN) é o agente etiológico de uma das doenças mais importantes da avicultura e tem sido identificado na maioria das espécies aviárias, silvestres e domésticas. Neste trabalho, obteve-se o isolamento em ovos embrionados da amostra denominada JAP99 do VDN, a partir de fezes de patos coletadas no Município de Japeri, RJ. A amostra

pathogenicity of the new isolate was investigated at the Animal Regional Laboratory, Ministry of Agriculture, Campinas, SP. By intracerebral inoculation in one day chicks, the index was 1.4. In the intravenous inoculation in birds of six weeks, the index found was 0.0 and the mean death time in chicken embryos was 62 hours. These results pointed out that the isolate JAP99 is mesogenic for commercial chickens, offering risk for the poultry industry.
\end{abstract} foi identificada pela técnica da inibição da hemaglutinação (HI) e a caracterização biológica da patogenicidade do novo isolado foi realizada no Laboratório Regional Animal, MAPA, Campinas, SP (LARA-Campinas). Pela inoculação intracerebral em pintos de um dia (IPIC), o índice foi 1,4. Na inoculação intravenosa em aves de seis semanas (IPIV), o índice encontrado foi 0,0 (zero) e o tempo médio de morte embrionária (TMME) foi de 62 horas. Estes resultados indicaram que o isolado JAP99 é mesogênico para galinhas comerciais, oferecendo risco para a avicultura industrial.

Palavras-chave: Paramyxovirus, doença de Newcastle, JAP99, patologia aviária.

\section{ABSTRACT}

Newcastle disease virus (NDV) is the etiological agent of one of the most important diseases of the poultry industry and it has been identified in most of the avian species, wild and domestic birds. In this work, the isolation of the sample denominated JAP99 was obtained from duck feces collected in Japeri, RJ, which was identified by hemagglutination-inhibition technique (HI). The biological characterization of the
Key words: Paramyxovirus, Newcastle disease, JAP99, avian pathology.

A doença de Newcastle é uma enfermidade viral, aguda, altamente contagiosa, que acomete aves comerciais e outras espécies aviárias, com sinais respiratórios, freqüentemente, seguidos por síndromes nervosas e entéricas. A manifestação clínica e a mortalidade variam segundo a patogenicidade da amostra viral (FIELDS et al., 1996). Como amostras virais de campo podem originar quadros clínicopatológicos que incluem desde mortalidade aguda a infecções respiratórias e entéricas brandas ou inaparentes (ALEXANDER, 1991), o diagnóstico laboratorial do vírus da doença de Newcastle (VDN) compreende o isolamento viral, seguido da caracterização biológica da patogenicidade do novo isolado (BRASIL, 1994).

\footnotetext{
${ }^{1}$ Agência Estadual de Defesa Sanitária Animal e Vegetal do Ministério da Saúde.

${ }^{2}$ Médico Veterinária, MSc, Universidade Federal Rural do Rio de Janeiro (UFRRJ), Seropédica, RJ, Brasil.

${ }^{3}$ Médico Veterinário, PhD, Laboratório Regional Animal de Campinas (LARA - MAPA), Campinas, SP, Brasil.

${ }^{4}$ Médico Veterinário, PhD, Laboratório Regional Animal de Campinas (LARA - MAPA), Campinas, SP, Brasil.

${ }^{5}$ Professor Adjunto, PhD, Instituto de Veterinária, UFRRJ, autor para correspondência UFRRJ, Br 465, Km 07, 23890-000, Seropédica, RJ, Brasil. E-mail: mazur@ufrrj.br. Autor para correspondência.

${ }^{6}$ Instituto de Veterinária, UFRRJ, Seropédica, RJ, Brasil.
} 
A primeira descrição da doença de Newcastle, no Brasil, data de 1953, quando Cunha e Silva realizaram o isolamento da amostra M33 do VDN, na cidade de Macapá, associando o surto da doença à importação de carcaças de frangos congelados, provenientes dos Estados Unidos (CUNHA \& SILVA,1955). A partir desta data, a doença foi observada em todo o território nacional, ocasionando graves perdas econômicas para os avicultores brasileiros (HASTENREITER, 1976; ITO et al., 1986). Mais recentemente, o MAPA reportou em junho de 2001, um surto no Estado de Goiás, que foi prontamente controlado (OIE Disease Information Report). Estudos sorológicos indicaram a circulação do VDN em aves silvestres no Estado do Rio de Janeiro (BELLUCCI et al., 1999). O Brasil, como um dos maiores exportadores mundiais de carne de frango, necessita de um rigoroso controle da circulação do VDN no território nacional, que possibilita a aceitação do nosso produto avícola nos mercados internacionais. O vírus da doença de Newcastle (VDN) é de grande importância econômica para avicultura industrial mundial e seu diagnóstico de rotina em laboratórios credenciados é preconizado pelas autoridades da Secretaria de Defesa Agropecuária do Ministério da Agricultura, Pecuária e Abastecimento - MAPA (BRASIL, 1994).

Para isolamento viral, ovos embrionados $S P F$ foram adquiridos da Granja Rezende, Uberlândia, MG. As hemácias utilizadas nas provas laboratoriais foram obtidas de galinhas soronegativas para o VDN, criadas a partir da incubação de ovos embrionados $S P F$, e mantidas em isolamento nas dependências do Laboratório de Viroses Veterinárias (LVV) do Departamento de Epidemiologia e Saúde Pública, do Instituto de Veterinária da UFRRJ. Para a identificação do isolado, o soro padrão positivo e soro negativo para VDN, e o antígeno viral empregado nas provas (VDN, amostra Ulster inativada) foram cedidos pelo Laboratório Regional Animal (LARA) MAPA, SP.

A investigação se originou a partir da notificação do proprietário de uma pequena propriedade rural no Município de Japeri, RJ com aproximadamente 150 aves (galinhas, patos e gansos) que apresentavam sinais e sintomas sugestivos de um surto de doença de Newcastle. Foi observada sintomatologia nervosa e respiratória caracterizada, principalmente, por incoordenação motora, forte diarréia e secreção respiratória. Mais de cem aves morreram, principalmente, patos domésticos (Neta sp). Esta propriedade apresentava manejo zootécnico inadequado, marcado por uma séria deficiência nos cuidados sanitários. Como fonte de água, as aves utilizavam um pequeno lago local freqüentado por aves silvestres, entre outros animais. Foram coletadas amostras de fezes e de sangue (punção da veia radial da asa) das aves doentes, que foram transportadas sob refrigeração para o LVV.

Para o isolamento em ovos embrionados, diluições decimais (de $10^{-1}$ a $10^{-3}$ ) de suspensões clarificadas de fezes foram inoculadas em cinco ovos embrionados $S P F$ de 8 a 11 dias de incubação, na dose de $0,1 \mathrm{~mL}$ via alantóica. Os embriões inoculados foram observados por ovoscopia duas vezes ao dia, por três dias consecutivos ou até a morte do embrião. Após este período, o líquido alantóico foi coletado e testado pela prova de hemaglutinação (HA). A prova de HA foi empregada para detecção da presença de vírus hemaglutinantes e sua titulação nos líquidos alantóicos dos embriões inoculados com material suspeito. A prova de HA foi realizada em placas de 96 cavidades com fundo em "U". Para determinação da identidade viral, foi utilizada a prova de inibição da hemaglutinação (HI) (ALEXANDER, 1989). Os soros positivo e negativo para VDN foram empregados como controles internos.

Para caracterização biológica do isolado, alíquotas do líquido alantóico hemaglutinante foram enviadas para o LARA-Campinas, onde foram realizados os testes de patogenicidade. Para obtenção do Índice de Patogenicidade Intracerebral (IPIC), 2 grupos de 10 pintos de 1 dia foram inoculados via intracerebral (IC) com líquido alantóico hemaglutinante, com título superior a 24UHA $50 \mu \mathrm{L}^{-1}$. O período de observação foi oito dias ou até a morte. Para o cálculo do IPIC, utilizou-se uma escala de pontuação na qual cada ave sadia corresponde a 0,0 (zero) pontos, aves doentes 1 ponto e aves mortas, 2 pontos, acumulados diariamente até o fim do experimento. O IPIC é definido pela média das pontuações dos grupos dividida pelo total acumulado de aves. Para determinação do Índice de Patogenicidade Intravenoso (IPIV), 2 grupos de 10 aves de 6 semanas de idade foram inoculados via intravenosa (IV), com o líquido alantóico hemaglutinante, com título superior a $24 \mathrm{UHA} 50 \mu \mathrm{L}^{-1}$. O período de observação das aves inoculadas foi de 10 dias, ou até a morte. Aves normais não recebem pontos, doentes recebem 1 ponto, paralíticas 2 pontos e mortas 3 pontos. O IPIV é definido pela média das pontuações dos grupos dividida pelo total acumulado de aves. Para obtenção do Tempo Médio de Morte Embrionária (TMME), após a realização de diluições decimais, $0,1 \mathrm{~mL}$ de cada diluição do líquido alantóico hemaglutinante foi inoculado em 5 ovos embrionados $S P F$ com 8 a 11 dias de incubação, via alantóica, e 
incubados a $37^{\circ} \mathrm{C}$. Os embriões foram observados por ovoscopia durante sete dias, duas vezes por dia, registrando-se o tempo decorrido em que cada embrião morto foi observado pela primeira vez. A morte dos embriões possibilita a obtenção da dose letal mínima, que corresponde à maior diluição capaz de matar todos os embriões. O TMME é o tempo médio em que a dose letal mínima mata os embriões inoculados.

A inoculação em ovos embrionados com suspensões de fezes provocou a morte dos embriões em 48 horas. O líquido alantóico coletado destes embriões foi analisado pela prova de $\mathrm{HA}$, que indicou a presença de vírus hemaglutinante. Em seguida, a suspeita da presença do VDN nas amostras de fezes foi comprovada através da prova de HI, utilizando-se o soro padrão positivo. Como resultado das provas de caracterização biológica, o IPIC encontrado foi de 1,42, o IPIV foi 0,0 e o TMME foi de 62 horas. De acordo com o PNSA (BRASIL, 1994), o TMME de 60 a 90 horas caracteriza um isolado viral mesogênico. Concluindo, o resultado comprova a circulação do VDN no Estado do Rio de Janeiro, oferecendo risco potencial para indústria avícola. Também se pode reafirmar que criações aviárias domésticas, comuns no interior e periferia de centros urbanos, com trânsito de aves silvestres e baixo nível zootécnico de manejo, podem atuar como reservatórios do VDN. O isolado JAP99 foi considerado patogênico, em função das provas biológicas descritas e da elevada mortalidade promovida a campo observada.

A doença de Newcastle, chamada velogênica, com IPIC acima de 0,7 (indicador de virulência viral) faz parte da Lista da OIE (Organização Internacional de Epizootias) e é de notificação obrigatória para os países signatários da Organização Mundial do Comércio (OMC). Desde 1953, a partir da sua primeira identificação no Brasil (CUNHA \& SILVA, 1955), a disseminação do VDN foi observada em todo território nacional, tendo representado um sério obstáculo para o desenvolvimento da indústria avícola nacional. A ocorrência desta doença no País acarreta a imediata suspensão das exportações de produtos avícolas, com graves prejuízos para os países dependentes do comércio internacional, como o Brasil. Em reconhecimento da importância da sanidade dos plantéis e do peso econômico da produção de frangos de corte, que projetou o Brasil entre os maiores exportadores mundiais, em 1994, o MAPA incluiu entre seus programas sanitários, o PNSA que prioriza o VDN como principal agente patogênico para as aves comerciais. Considerada endêmica por 25 anos em várias regiões, em 2003, o governo brasileiro declarou o País livre desta doença, com reconhecimento da OIE, a partir de um levantamento oficial realizado em 2002.

O PNSA é estruturado através de uma rede de laboratórios oficiais e credenciados que promovem a vigilância nos principais pólos de produção. Esta vigilância se baseia em notificações obrigatórias, assistência aos focos, medidas de biossegurança, desinfecção e sacrifício, entre outras. Contudo, por se tratar de um vírus que infecta, possivelmente, todas as espécies aviárias, incluindo aves silvestres de vida livre ou cativeiro e de criações caseiras, estes reservatórios talvez venham sendo relegados e são analisados apenas por poucos pesquisadores envolvidos em estudos nestas populações, como no presente trabalho. Também se deve ter em conta que tais aves dificilmente têm assistência veterinária, como fator agravante. Em relação às aves de fundo de quintal, devem ser considerados ainda os aspectos sócioeconômicos envolvidos, lembrando-se que a prática do sacrifício sanitário não é acompanhada de uma política de indenização. Logo, o pequeno criador muitas vezes restringe o acesso da sua propriedade aos grupos de pesquisa.

Apesar de todos os esforços, diante do difícil acesso aos reservatórios silvestres e domésticos, o status internacional do Brasil como área livre está sempre ameaçado, carecendo portanto de providências adicionais. Entre estas, as pesquisas sorológicas e tentativas de isolamento nas populações citadas, embora esparsas, apontam a importância deste tipo de investigação, direcionando, eventualmente, as autoridades sanitárias para os possíveis focos, como ocorreu em Japeri, após o isolamento aqui relatado. Neste caso, a propriedade foi interditada, todas aves foram sacrificadas e outras medidas profiláticas foram tomadas pelos agentes sanitários do MAPA. Contudo, a questão justifica um esforço conjunto dos pesquisadores, em nível nacional, incluindo o esclarecimento sobre o controle do VDN, veiculado pelos reservatórios referidos. A característica destes hospedeiros alternativos, normalmente populações flutuantes, pressupõe uma vigilância perene. A vacinação e melhoria das condições zootécnicas, para os pequenos criadores de aves caipiras, o isolamento sanitário de criações industriais das aves de vida livre e a vigilância sorológica e virológica constante poderiam contribuir para redução do problema. O controle sanitário de aves silvestres apreendidas, antes da sua reintrodução na natureza também deve ser considerado. Com base neste trabalho e outros citados, pode-se preconizar uma colaboração, em nível nacional, de pesquisadores do assunto que implementem um

Ciência Rural, v. 35, n.4, jul-ago, 2005. 
sistema integrado de vigilância nestes reservatórios alternativos, em consonância com o PNSA. Esta complementação poderá ser extremamente oportuna e favoreceria de sobremaneira a manutenção da condição de área livre, bem como a credibilidade do Brasil, junto à comunidade científica e comercial internacional.

\section{AGRADECIMENTOS}

À Fundação Carlos Chagas Filho de Amparo à Pesquisa do Estado do Rio de Janeiro FAPERJ pelo suporte financeiro e ao $\mathrm{CNPq}$ pelas bolsas concedidas.

\section{REFERÊNCIAS}

ALEXANDER, D.J. Newcastle disease V. In: A laboratory manual for the isolation and identification of avian pathogens. 3.ed. Kennett Square, PA : American Association of Avian Pathologists, 1989. Cap.27, p.114120 .
ALEXANDER, D.J. Diseases of poultry. 9.ed. Iowa : B.W. Ames, Calnek, H.J. Barnes, C.W. Beard, W.M. Reid \& H.W. Yoder, Jr, 1991. Cap3, p.496-519.

BELLUCI, M.S.P. et al. Avaliação sorológica do vírus da doença de Newcastle em aves silvestres. Rev Bras Ci Vet, v.6, n.2, p.66-68, 1999.

BRASIL - MAPA. Programa Nacional de Sanidade Avícola. Portaria no 183 de 08 de novembro de 1994 - Secretaria de Defesa Agropecuária.

CUNHA, R.G.; SILVA, R.A. Isolamento e identificação do vírus da Doença de Newcastle no Brasil. Soc Bras Med Vet v.23, p.17-33, 1955.

FIELDS, B.N. et al. Fundamental virology. 3.ed. Philadelphia, PA : Lippincott-Raven 1996. 1339p.

HASTENREITER, H. La maladie de Newcastle au Brésil. Bull Off Int Epiz, v.85, p.813-817, 1976.

ITO, N.M.K. et al. Newcastle disease virus: some biological characteristics of twelve samples isolated in Brazil. Rev Fac Med Vet Zootec Univ S Paulo, v.23, n.1, p.47-53, 1986. 